\title{
Zeylanidium as Pollution Indicators: Live Sensors to Water Parameters
}

\author{
Thara K. Simon*, Veena Mathew, S. L. Sreekala \\ Department of Botany, Union Christian College, Aluva, (Affiliated to Mahatma Gandhi University) Kerala, India \\ Email: *tharasimon@yahoo.com
}

How to cite this paper: Simon, T.K., Mathew, V. and Sreekala, S.L. (2018) Zeylanidium as Pollution Indicators: Live Sensors to Water Parameters. Open Access Library Journal, 5: e4518. https://doi.org/10.4236/oalib.1104518

Received: March 19, 2018

Accepted: May 13, 2018

Published: May 16, 2018

Copyright $\odot 2018$ by authors and Open Access Library Inc.

This work is licensed under the Creative Commons Attribution International License (CC BY 4.0).

http://creativecommons.org/licenses/by/4.0/

\section{(c) (i) Open Access}

\begin{abstract}
Podostemaceae family is well known as a group of aquatic angiosperms with enigmatic characters. The present work was performed to trace ecological aspects, phenology, water analysis and phylogenetic analysis of the genus Zeylanidium, in order to establish the uniqueness of the species in the fresh water habitats S-1 $\left(9.9559^{\circ} \mathrm{N}, 76.8339^{\circ} \mathrm{E}\right)$ and S-2 $\left(10.0538^{\circ} \mathrm{N}, 76.8294^{\circ} \mathrm{E}\right)$. Through water analysis it is revealed that the species of plants could be used as an indicator of pollution as they are present in very sensitive area of running fresh water. The phenology of the taxa understudy paved light to the co-existence of Zeylanidium maheshwari and Zeylanidium lichenoides. The data on comparison of molecular and phylogenic tree reveal that the species are highly related genetically for a sustainable coexistence.
\end{abstract}

\section{Subject Areas}

Plant Science

\section{Keywords}

Zeylanidiumas

\section{Introduction}

Podostemaceae is the largest family of submerged flowering plants having unusual morphology and reproductive characters. Recent results based on molecular analysis indicate that Podostemaceae belongs to the Malpighiales clade, most closely related to Clusiaceae and Hypericaceae. Tristichoideae and Weddellinoideae are acceptable as podostemaceous subfamilies, which are clearly distinguishable from the large subfamily Podostemoideae [1] [2].

Geetha [3] and Girija [4] studied the ecological aspects of Podostemacae present in Kerala by assigning different sites of Kerala into highland, lowland and 
midland based on topology and elevation from main sea level. They have studied the geology and rock specificity of the taxa. Gareenand Gyure [5] characterized bacterial communities associated with members of the plant family Podostemaceae. Cyanobacteria (blue green bacteria) play a major role in the secretion of adhesive compounds that allow these plants to attach to rocks in waterfalls, and thus survive rapid flowing water and rapidly changing environmental conditions.

Most authors have classified the family into two subfamilies, Podostemoideae and Tristichoideae [6] [7] [8] [9] Engler [10] divided Podostemaceae into three subfamilies such as Podostemoideae (35 genera), Tristichoideae (three genera), and Weddellinoideae (monotypic). The molecular data support them as independent lineages [2] [11].

The Podostemaceae are strictly aquatic and tropical and are seen in unique habitat attached to rocks in river rapids and waterfalls. They have adopted many special anatomical and morphological characters [12] in order to counteract the destructive force of water. Earlier it was believed that they were attached to the rocks by means of a cementing material secreted from their haptera [13]. Later the studies conducted by the Jager-Zurm and Grubert [14] revealed that the strong attachment of the taxa to the substratum is via an extracellular polymeric substance of the bacterial biofilm present in their habitat. Moline et al. [11] studied the matK sequence data along with morphological data of eight African species of Podostemaceae belonging to the genera Dicraeanthus, Dijnga and Ladermanniella. Khanduri et al. [15] carried out a phylogenetic study of the Indian Podostemaceae using its sequence data and morphological characters. The phylogenetic analysis reveals that the Indian Podostemoideae is subdivided into two subclades; one represented by Willisia and Podostemum and the other by Zeylanidium, Hydrobryopsis, Griffithella and Polypleurum.

The present conducted during South-West monsoon 2013 through summer 2017 in order to focus on ecological aspects, phenology, water analysis and phylogenetic analysis of the podostemaceae genus Zeylanidium, and to establish the uniqueness of the species in the fresh water habitats.

\section{Materials and Methods}

Fresh water habitats S-1 $\left(9.9559^{\circ} \mathrm{N}, 76.8339^{\circ} \mathrm{E}\right)$ and S-2 $\left(10.0538^{\circ} \mathrm{N}, 76.8294^{\circ} \mathrm{E}\right)$ were selected after pilot study for presence of the selected study species. Clear water samples close to the species under study that extends $0.5 \mathrm{~m}$ to $1 \mathrm{~m}$ vertical depth were obtained using insulated bottles and brought to the laboratory to study the parameters such as dissolved oxygen, free Carbon dioxide, alkalinity [16], nitrite determination and sulphate.

Soon after collection, plants were examined in order to establish correct identification and also referred with flora [17]. Technical terms for external appearance of the plant structures are given in order to explain the morphological features of the species under study and they are adopted from previous explana- 
tions given by Girija [4], Mathew and Satheesh [18] and Nileena [19]. The characters and the character states considered for the present study is given in Table 1. The selected morphological characters were used to create a matrix and evolutionary tree were drawn using Mesquite's heuristic tree search and a consensus tree were generated by using Mesquite 2.75 [20]. In order to study the phylogeny of the family podostemaceae and to infer the systematic position of Zeylanidium the character optimization of morphological characters was examined by using Mesquite 2.75 [20] molecular systematic analysis was done by using the gene matK.

The matK genes of the different species of Podostemaceae along with 1 out group (clussiaceae) were retrieved from genbank of National centre for biotechnological information (http://www.ncbi.nlm.nih.gov/genbank/) (Table 2).

The sequences were aligned using ClustalX 2.0.11 [21]. The gaps and missing data were eliminated. Phylogenetic analyses were done using Bayesian (maximum posterior probability, MPP), maximum parsimony (MP), and neighborjoining (NJ). Phylogenetic analyses by MP [22] [23] [24] and NJ [24] methods were conducted using MEGA ver. 6 [25].

\section{Results and Discussions}

S-1 a low-land area $\left(9.9559^{\circ} \mathrm{N}, 76.8339^{\circ} \mathrm{E}\right)$ and S-2 a high-land area $\left(10.0538^{\circ} \mathrm{N}\right.$, $76.8294^{\circ} \mathrm{E}$ ), which experiences tropical climate and belongs to Idukki district. Hornblende-biotite gneiss rock is the major type of rock present in these sites. Zeylanidium maheshwarii and Zeylanidium lichenoides were collected along with Polypleurum stylosumin S-1. (S-2) is the midland area of Idukki district. Water sampling data of the two sites are given in Table 3. The site experiences subtropical climate and possess charnockite rocks. Zeylanidium olivaceum flourishes well here along with Zeylanidium maheshwarii.

Phenological patterns of podostemads under study are represented in phenograms. In Thommenkuth, Zeylanidium maheshwarii and Zeylanidium lichenoides can be seen. They grow intermingled and show a similar phenology. Hence the co-occurance of both this taxa gives a strong relationship between them. According to Willis [17] the water level and position of taxon on the rocks control the phonological pattern of these taxa in a specific region. As the genus Zeylandium resides on higher rock position this may be the reason why they show similar phenological pattern. The phenological pattern of Zeylanidium olivaceum is slightly different from Figure 1. Phenogramother two taxon. According to Girija [4] this difference stands even though they are seen along with other taxa (Figure 2).

The topology of maximum likelihood tree $(\mathrm{ML})$, maximum parsimony tree (MP), and neighbour-joining tree (NJ), Mr bayes tree are similar indicating the reliability of the phylogenetic tree that have been drawn and presented in Figure 3. In the molecular phylogeny tree, two clades can be identified-1. Tristichoideae, 2. Podostemoideae. Hence the monophyly of each subfamily were 
Table 1. Morphological characters and character states used in the study.

\begin{tabular}{|c|c|}
\hline Character & Character states \\
\hline shoots & $0=$ monomorphic, $1=$ dimorphic \\
\hline Leaf base & $0=$ narrow attachment point, $1=$ sheathing \\
\hline stipules & $0=$ absent, $1=$ present \\
\hline Leaf type & $0=$ simple, $1=$ compound $2=$ ramulus \\
\hline Leaves & $0=$ monomorphic, $1=$ dimorphic \\
\hline Vegetative stem length & $0=$ less than $1,1=1-5 \mathrm{~cm}, 2=$ greater than $5 \mathrm{~cm}$. \\
\hline shoot position & $\begin{aligned} 0= & \text { only at sinus of thallus branching, } 1=\text { on lateral flank along length of thallus } \\
& \text { including the sinus of thallus branching dorsal surface in foliose thallus. }\end{aligned}$ \\
\hline Double sheathing leaf & $0=$ absent, $1=$ present \\
\hline Maximum leaf length & $0=1 \mathrm{~cm}, 1=1-5 \mathrm{~cm}, 2=$ above 5 \\
\hline spathella & $0=$ absent, $1=$ present \\
\hline Spathella tip & $0=$ round, $1=$ pointed, $2=$ beaked \\
\hline Spatella surface & $0=0=$ smooth, $1=$ hairy \\
\hline Spatella rupture & $0=$ longitudinal, $1=$ irregularly at the apex. \\
\hline Cupule & $0=$ absent, $1=$ present. \\
\hline symmetry of flower & $0=$ actinomorphic, $1=$ zygomorphic . \\
\hline Flower grouping & $0=$ soilitary, $1=$ cluster \\
\hline flower pedicel & $0=$ absent, $1=$ present \\
\hline flower orientation at anthesis & $0=$ vertical, $1=$ dorsiventral, $2=$ oblique \\
\hline floral bract & $0=$ absent, $1=$ present. \\
\hline Bract & $0=$ absent, $1=$ simple, $2=$ digitate \\
\hline Perianth & $0=$ absent, $1=$ present \\
\hline tepal & $0=$ six or more in complete whorl, $1=5$ as complete $2=2,3=3$ as complete whorl. \\
\hline Staminode & $0=$ absent, $1=$ present \\
\hline third staminode in anthropodium & $0=$ absent, $1=$ present \\
\hline andropodium & $0=$ absent, $1=$ present \\
\hline stamen whorls & 1 complete whorl, 2 = additional whorl. \\
\hline Number of stamens & $0=$ more than $3,1=2,2=3,3=1$. \\
\hline pollen aperture & $0=$ pantoporate (polyporate), $1=$ tricolporate, $2=$ tricolpate \\
\hline pollen & $0=$ monad, $1=$ dyad \\
\hline Carpel number & $0=2,1=3$ \\
\hline Symmetry of ovarian locules & $0=$ isolobulous, $1=$ anisolobilous \\
\hline locule number & $0=2,1=3,2=1$ \\
\hline stigma lobe & $0=2,1=3,2=$ multilobed. \\
\hline Stigma form & $0=$ linear, $1=$ fan shaped, $2=$ capitate. \\
\hline Stigma margin & $0=$ entire, $1=$ irregular. \\
\hline Stigma lobe & $0=$ equal, $1=$ unequal \\
\hline gynopore & $0=$ absent, $1=$ present \\
\hline Ovary position inspatella & $0=$ erect, $1=$ oblique, $2=$ inverted \\
\hline capsule shape & $0=$ globose, $1=$ elliptical, $2=$ globular - ellipsoid \\
\hline capsule morphology & $0=$ absent $($ smooth), $1=$ present $($ ribbed $)$. \\
\hline Number of rib per valve & $0=$ nil, $1=3,2=$ more than 3 \\
\hline capsule valves & $0=$ persistent, $1=1$ deciduous \\
\hline
\end{tabular}


Table 2. The matK genes of different species of Podostemaceae.

\begin{tabular}{ccc}
\hline Taxon & Locality & \\
\hline Dalzellia zeylanica & Sree Lanka & $\mathrm{AB} 450023$ \\
Farmeriametzgerioides & Sree Lanka & $\mathrm{AB} 698232$ \\
Griffithella hookeriana & Kerala & $\mathrm{AB} 698236$ \\
Hydrobryopsis sessilis & Kerala & $\mathrm{AB} 698240$ \\
Hydrobryum griffithii & Thailand & $\mathrm{AB} 104570$ \\
Podostemum subulatum & & $\mathrm{AB} 038207$ \\
Polypleurum munnarense & Kerala & $\mathrm{AB} 610267$ \\
Polypleurum stylosum & & $\mathrm{AB} 066174$ \\
Willisia selaginoides & & $\mathrm{AB} 698236$ \\
Zeylanidium lichenoides & Kerala & $\mathrm{AB} 048828$ \\
Zeylanidium maheshwarii & Kerala & $\mathrm{AB} 048379$ \\
Zeylanidium olivaceum & Sri Lanka & $\mathrm{AB} 038207$ \\
Clussia criuva & & $\mathrm{AB} 450037$ \\
\hline
\end{tabular}

Table 3. Water sampling data.

\begin{tabular}{ccc}
\hline Parameter & $(\mathrm{S}-1)$ & $(\mathrm{S}-2)$ \\
\hline Dissolved oxygen & $9.3 \mathrm{mg} / \mathrm{l}$ & $10.73 \mathrm{mg} / \mathrm{l}$ \\
Free carbondioxide & $6.16 \mathrm{mg} / 1$ & $5.28 \mathrm{mg} / \mathrm{l}$ \\
Alkalinity & $20 \mathrm{ppm}$ & $50 \mathrm{ppm}$ \\
Nitrite & $\mathrm{Nil}$ & $\mathrm{Nil}$ \\
Sulphate & $\mathrm{Nil}$ & $\mathrm{Nil}$ \\
\hline
\end{tabular}

Site 1

Zeylanidium lichenoides

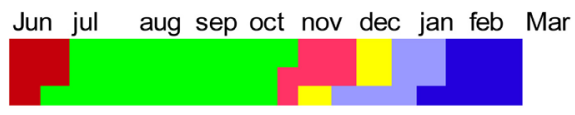

Zeylanidium maheshwarii

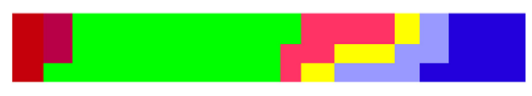

Polypleurum stylosum*

Site 2

Zeylanidium olivaceum

Zeylanidium maheshwani
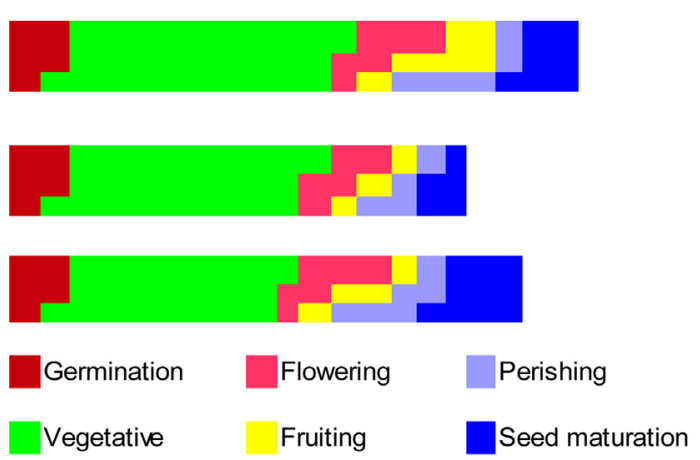

Figure 1. Phenological pattern of podostemacae under study.

supported, in accordance with earlier studies [2] [11] [15]. The clade Tristichoideae includes Dalzellia zeylanica and Indotristica ramossisima. The Podostemoideae is divided into two sub-clades. One clade comprises of Podostemum subulatum, 


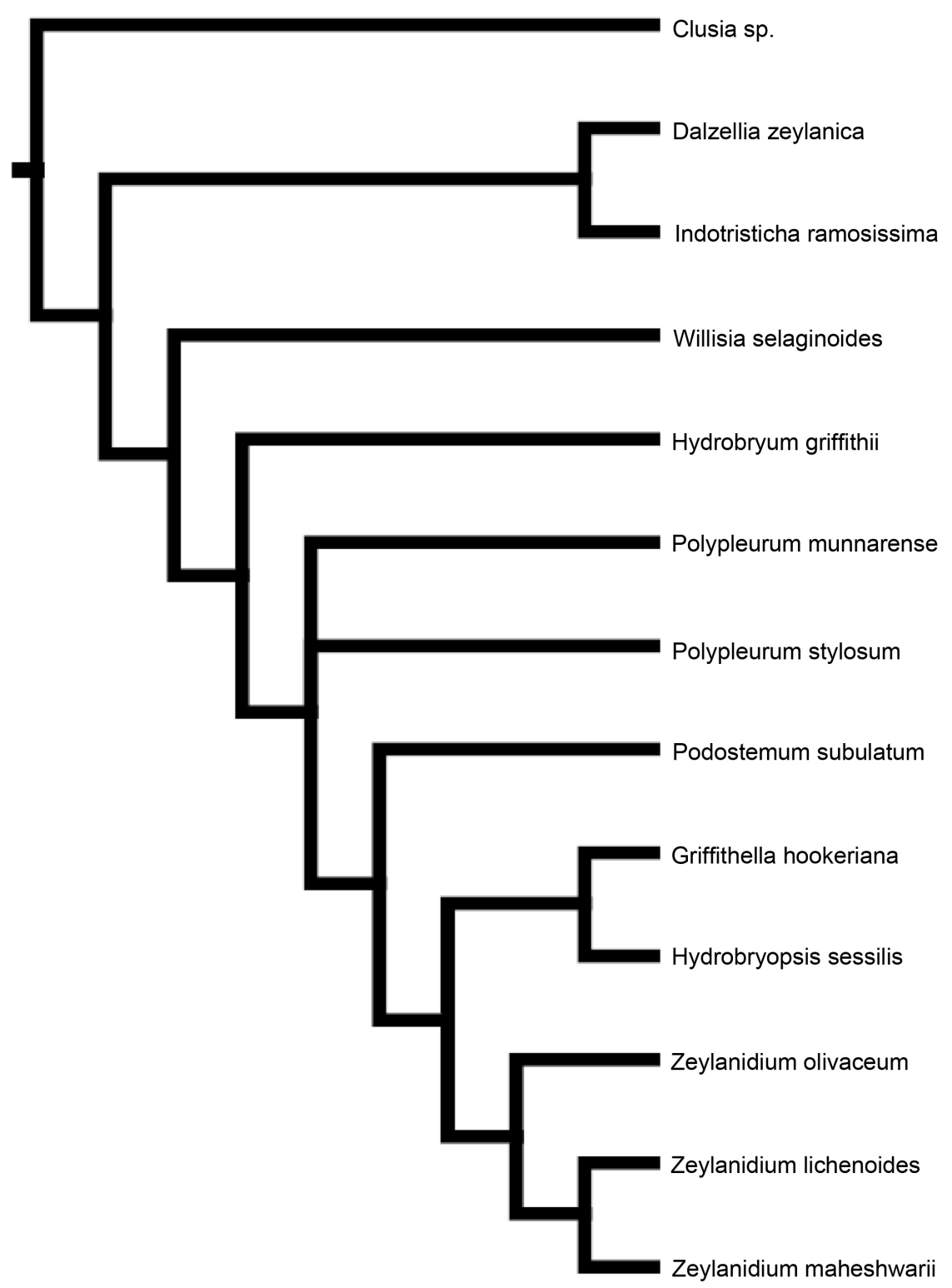

Figure 2. Morphological tree of Indian Podostemaceae.

Griffithella hookeriana, Polypleurum stylosum, and Polypleurum munnarense and the other includes Willisia selaginoides, Hydrobryopsis sessilis, Zeylanidium lichenoides, Zeylanidium maheshwarii and Zeylanidium olivaceum. This is in agreement with the study of Khanduri et al. [15], which showed that Willisia and Podostemum form a clade and Polypleurum, Hydrobryopsis, Griffithella and Zeylanidium forms another clade.

The analysis of morphological characters yielded a consensus tree. It has much similarity with the tree drawn by molecular phylogeny. It also yielded two clades-Tristichoidae and Podostemoidae. The difference with the molecular phylogenetic tree is in the positioning of Griffithella hookeriana. Here Zeylanidium maheshwarii and Zeylanidium lichenoides becomes a clade while in the molecular phylogenetic tree Zeylanidium maheshwarii and Zeylanidium olivaceum 


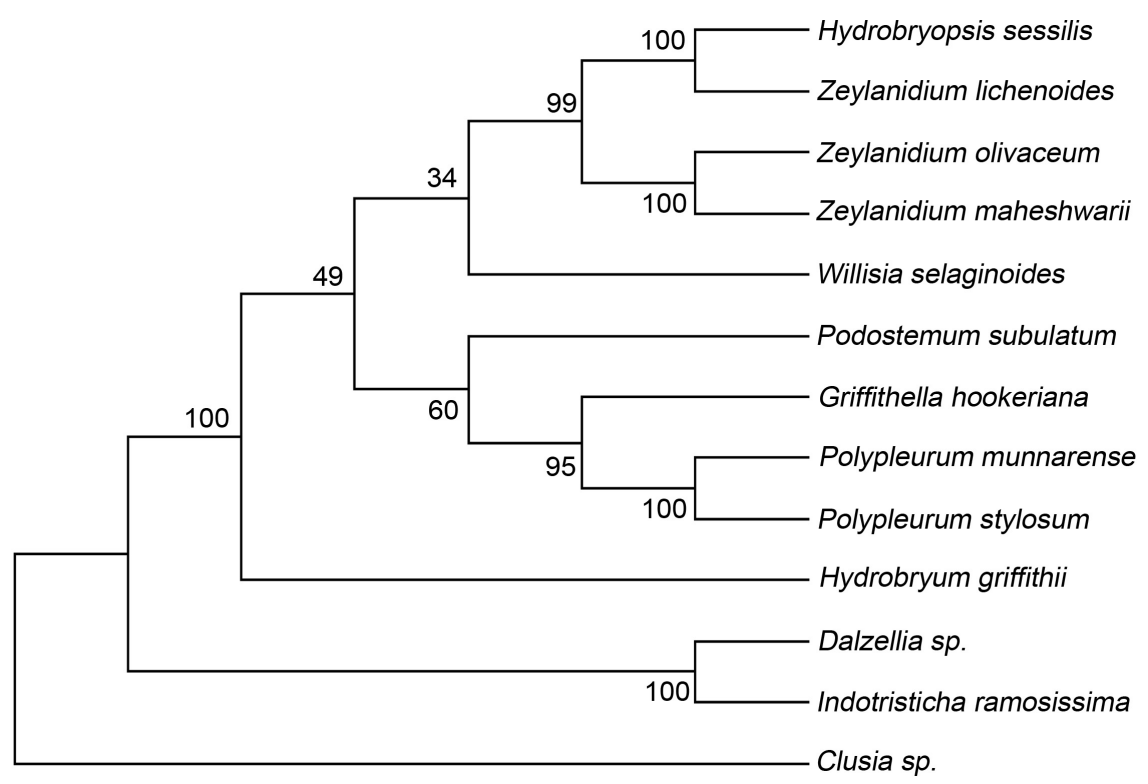

Figure 3. Maximum parsimony tree of Indian Podostemaceae.

becomes a clade. In both the phylogenetic trees the genus Zeylanidiumis closely related to Hydrobryopsis sessilis. Cusset and Cusset [1] proposed that the Indian species of Podostemum should be shifted to the genus Zeylanidium. However the present morphological and phylogenetic analysis suggests that the Indian species of Podostemum should not be included in the genus Zeylanidium.

\section{Conclusion}

Zeylanidium lichenoides is a widely distributed genus and maximum distribution of this taxon indicates it's primitiveness in the lowland. Zeylanidium maheshwarii is a highly restricted species growing well on the dorsal surface of rocks. The taxa show a close association with Zeylanidium lichenoides. There occurs a marked similarity between the taxa in terms of phenology. This along with the co-occurrence of the taxa indicates the closeness of the taxa. Co-occurrence is an interesting phenomenon and important from the evolutionary point of view. Sometimes co-occurrence may result in hybridization and probably through this incidence, self-fertilized and homozygous plants will show variability in their genome. Eventually they will be able to survive, compete and show wider distribution. Thus Zeylanidium lichenoides has followed this strategy and Zeylanidium maheshwarii appears to have evolved as a new species from this through a slight change in the environmental conditions, water regime and water chemistry. The co-occurrence of Zeylanidium maheshwarii with Zeylanidium lichenoides benefits the taxon by giving protection, animal visits and also ensure continuous water supply. Considering all these, Zeylanidium lichenoides can be considered as the primitive one. Zeylanidium maheshwarii has got an advanced position with specific requirements. The sister group concept of this taxa generated by mat $\mathrm{k}$ gene phylogenetic analysis gives additional support 
to this family. The phenology of the taxa under study paved light to the co-existence of Zeylanidium maheshwari and Zeylanidium lichenoides. The data on comparison of molecular and phylogenic tree reveal that the species are highly related genetically for a sustainable coexistence. Identification of plants with such characters can be high significance in future habitat and species conservation programs. The family Podostemaceae is seen in the water falls of Western Ghats regions indicating its need of specific substratum for growth. Also earlier studies indicate their close association with Cyanobacteria. Such associations might have some direct relationship with the existence and life cycle pattern of Podostemaceae, which has to be resolved by further studies.

\section{References}

[1] Cusset, C. and Cusset, G. (1988) Etude sur les Podostemales: 10. Structures vegetativesetflorales des Tristichaceae. Bulletin du Muséum National d'Histoire Naturelle Section B,Adansonia, botanique, phytochimie, 2, 179-218.

[2] Kita, Y. and Kato, M. (2001) Infrafamilial Phylogeny of the Aquatic Angiosperm Podostemaceae Inferred from the Nucleotide Sequence of the matK Genes. Plant Biology, 3, 156-163. https://doi.org/10.1055/s-2001-12895

[3] Geetha, K. (2002) Autecology and Reproductive Biology of the Family of Podostemaceae in Kerala. PhD Thesis, MG University, Kottayam.

[4] Girija, K.D. (2007) Ecological and Phytochemical Studies in the Family Podostemaceae. PhD Thesis, MG University, Kottayam.

[5] Gareen, K. and Gyure, R.A. (2007) A Study of Bacterial Communities Associated with Podostemaceae Biofilms. Western CT State University, Danbury.

[6] Von Royen, P. (1953) The Podostemaceae of the New World. Part III. Acta Botanica Neerlandica, 3, 215-263. https://doi.org/10.1111/j.1438-8677.1953.tb00265.x

[7] Thakthajan, A. (1980) Outline of the Classification of Flowering Plants (Magnoliophyta). Botanical Review, 46, 226-339.

[8] Throne, R.F. (1992) An Updated Phylogenetic Classification of the Flowering Plants. Aliso, 13, 365-389. https://doi.org/10.5642/aliso.19921302.08

[9] Schnell, R.A.A. (1998) Anatomie des podostemaceae In: Landolte Janger-Zeurn, I. and Schnell, R.A.A., Eds., Extreme Adaptions in Angiosperms Hydrophytes Encyclopedia of Plant Anatomy XIII, 4: 197-290.

[10] Engler, A. (1930) Podostemaceae in Engler \& Prantl. Die Naturalichen Pfanzen Familien, 2nd Edition, I-68, 483-484.

[11] Moline, P., Thiv, M., Ameka, G.K., Ghogue, J.-P., Pferifer, E. and Rutishauser, R. (2007) Comparative Morphology and Molecular Systematics of African Podostemaceae-Podostemoideae, with emphasis on Dicraeanthus and Ledermanniella from Cameron. International Journal of Plant Sciences, 168, 159-180. https://doi.org/10.1086/509607

[12] Pannier, F. (1960) Physiological Response of Podostemaceae in Their Natural Habitat. Internationale Revue der gesamten Hydrobiologie und Hydrographie, 45, 347-354.

[13] Vidyashankari, B. (1998) Seed Germination and Seedling Morpholgy in Inotristicharamosissima (Podostemaceae) Grown in Vitro. Current Science, 57, 369-373.

[14] Jager-Zurn, I. and Grubert, M. (2000) Podostemaceae Depend on Sticky Biofilm 
with Respect to Attachment to Rocks in Waterfalls. International Journal of Plant Sciences, 161, 599-604. https://doi.org/10.1086/314292

[15] Khanduri, P., Tandon, R., Unniyal, P.L., Bhat, V. and Pandey, A.K. (2014) Comparative Morphology and Molecular Systematics of Indian Podostemaceae. Plant Systematics and Evolution, 301, 861-882.

[16] APHA (1998) Standard Methods for the Examination of Water and Waste. 20th Edition, American Public Health Association, American Water Works Association, Water Pollution Control Federation, Washington DC.

[17] Willis, J.C. (1902) Studies in the Morphology and Ecology of the Podostemaceae of Ceylon and India. Annals of the Royal Botanic Gardens Peradeniya, 1, 181-250.

[18] Mathew, C.J. and Satheesh, V.K. (1996) Zeylanidiummaheshwari: A New Species of the Family Podostemaceae in Kerala. Aquatic Botany, 54, 73-78. https://doi.org/10.1016/0304-3770(95)01003-3

[19] Nileena, C.B. (2001) Detailed Studies on Genera and Species of the Family Podostemaceae with Particular Reference to the Phenomenon of Polymorphism. PhD Thesis, Mahatma Gandhi University, Kottayam.

[20] Maddison, W. and Maddison, D. (2009) MESQUITE: A Modular System for Evolutionary Analysis. Evolution, 11.

[21] Thompson, J.D., Gibson, T.J., Plewniak, F., Jeanmougin, F. and Higgins, D.G. (1997) The ClustalX Windows Interface: Flexible Strategies for Multiple Sequence Alignment Aided by Quality Analyses Tools. Nucleic Acids Research, 25, 4876-4882. https://doi.org/10.1093/nar/25.24.4876

[22] Fitch, W.M. (1971) Toward Defining the Course of Evolution Minimal Change for a Specific Tree Topology. System Zool, 20, 406-416. https://doi.org/10.2307/2412116

[23] Swofford, D.L. (1996) PAUP: Phylogenetic Analyses using Parsimony (and Other Methods), Version 4.0. Sinauer, Sunderland.

[24] Saitou, N. and Nei, M. (1987) The Neighbour-Joining Method: A New Method for Reconstructing Phylogenetic Trees. Molecular Biology and Evolution, 4, 406-425.

[25] Tamura, K., Stecher, G., Peterson, D., Filipski, A. and Kumar, S. (2013) MEGA6: Molecular Evolutionary Genetics Analysis Version 6.0. Molecular Biology and Evolution, 30, 2725-2729. https://doi.org/10.1093/molbev/mst197 